\title{
Emancipatory practices of nurses in primary health care: the home visit as an instrument of health needs assessment*
}

\author{
PRÁTICAS EMANCIPATÓRIAS DE ENFERMEIROS NA ATENÇÃO BÁSICA À SAÚDE: \\ A VISITA DOMICILIAR COMO INSTRUMENTO DE RECONHECIMENTO \\ DE NECESSIDADES DE SAÚDE
}

\author{
PRÁCTICAS EMANCIPADORAS DEL ENFERMERO EN LA ATENCIÓN PRIMARIA DE \\ SALUD: LA VISITA DOMICILIARIA COMO INSTRUMENTO DE RECONOCIMIENTO DE \\ NECESIDADES DE LA SALUD
}

\section{Celia Maria Sivalli Campos ${ }^{1}$, Bárbara Ribeiro Buffette Silva², Deisi Cristine Forlin², Carla Andréa Trapé ${ }^{4}$, lara de Oliveira Lopes ${ }^{5}$}

\begin{abstract}
Objective: Identify nurses' emancipatory practices in primary care, to contribute to the improvement of health care. Method: A case study type social research of qualitative nature, in which nurses of a primary health care service unit in São Paulo were interviewed. Results: The home visit was identified as a nursing practice possible to be expanded in order to identify social determinants of health, triggering emancipatory practices in the service. This expansion occurred because the design of health care labour intended by the service team changed its focus from the traditional object of health services, the disease. Conclusion: First, it is advocated that social policies lead projects with the purpose of improving health needs. On the other hand, the daily labour needs to provide opportunities for reflection and discussion of healthcare projects, leading workers to propose labourprocesses targeted to both the social determinants of health and people's illness.
\end{abstract}

\section{RESUMO}

Objetivo: Identificar as práticas emancipatórias de enfermeiros da Atenção Primária, com a finalidade de contribuir para o aprimoramento do cuidado em saúde. Método: Pesquisa social de natureza qualitativa, do tipo estudo de caso. Foram entrevistados os enfermeiros de uma Unidade de Saúde da Família em São Paulo. Resultados: Identificou-se que a visita domiciliária, prática protocolar, ampliou seu escopo e identificou determinantes do processo saúde-doença, desencadeando na Unidade de Saúde da Família práticas emancipatórias. Essa ampliação ocorreu porque o projeto de cuidado intencionalizado ampliou o objeto tradicional dos serviços de saúde. Conclusão: Advoga-se que as diretrizes das políticas sociais ancorem projetos que tomem como finalidade o aprimoramento das necessidades de saúde e que o cotidiano do trabalho proporcione reflexão e discussão dos projetos de cuidado, para intencionalizar práticas que incidam nos determinantes do processo saúde-doença, tanto quanto nos resultados - a doença expressa no corpo individual.

\section{DESCRITORES:}

Visita domiciliária

Atenção Primária à Saúde

Enfermagem em saúde pública

Estratégia Saúde da Família

Prática de saúde pública

Necessidades e demanda de serviços de saúde

\section{RESUMEN}

Objetivo: Identificar las prácticas emancipadoras de enfermeras en Unidad de Salud Familiar fueron el objeto de este estudio. Método: La investigación social cualitativa tipo estúdio de caso. Fueron entrevistados enfermeros de una Unidad de Salud Familiar en Sao Paulo. Resultados: Se identificó que la Visita Domiciliaria ha ampliado su alcance y identificado determinantes del proceso salud-enfermedad, lo que provocó en la Unidad de Salud Familiar prácticas emancipadoras. Esta expansión se produjo debido a que el diseño de la atención en propósito por la USF amplió el tradicional objeto de los servicios de salud. Conclusión: Se aboga que las directrices de las políticas sociales basen proyectos que tengan como fin el mejoramiento de las necesidades de salud y que el trabajo diario proporcione la reflexión y discusión de los proyectos de atención, para proponer prácticas que enfoquen en los determinantes del proceso salud-enfermedad, tanto cuanto en sus resultados - la enfermedad en el cuerpo individual.

\section{DESCRIPTORES:}

Visita domiciliaria

Atención Primaria de Salud

Enfermería em salud publica

Estrategia de Salud Familiar

Práctica de salud pública

Necesidades y demandas de servicios de salud

\footnotetext{
"Extract from the dissertation "Práticas de enfermeiras da USF Jardim Boa Vista: em pauta a participação social", Nursing School, University of São Paulo; 2012. ${ }^{1}$ Associate Professor, Department of Collective Health Nursing, Nursing School, University of São Paulo, São Paulo - São Paulo, Brazil. ${ }^{2}$ Master of Sciences, Nursing School, University of São Paulo, São Paulo - São Paulo, Brazil. ${ }^{3}$ Master's student, Nursing Graduate Program, Nursing School, University of São Paulo, São Paulo - São Paulo, Brazil. ${ }^{4}$ Ph.D. in Sciences, Nursing School, University of São Paulo, São Paulo - São Paulo, Brazil. ${ }^{5}$ Family Health Nurse, Municipal Health Department of São Paulo, São Paulo - São Paulo, Brazil.
} 


\section{INTRODUCTION}

Emancipatory practices performed by nurses in primary care services are the object of the present study. Emancipatory practices are defined as actions that enable reflection about the origin of health problems, the determinants of the health-sickness process. These practices enable persons to access and fight for their rights, enhancing solidarity values and rescuing the human condition as a social condition, opposing the biological focus ${ }^{(1)}$. Emancipatory practices have been defined this way in the developing process of research about nursing practices ${ }^{(a)}$.

The expression emancipatory practices was found in health literature as a call to nurses to take part in the critical movement that proposes overthrowing traditional models of health care services ${ }^{(2)}$.

Regarding nursing practices, although a variety of theories, methods and methodologies have been developed ${ }^{(3)}$, and despite attempts to formulate critical methods in the academic scope, clinical methods based on the normal working pattern of the human organism are dominant. Since these methods are acknowledged as instruments to provide care, nursing practices have been primarily focused on organs and systems malfunctions ${ }^{(4)}$.

Primary care (PC) health practices in Brazil follow the Family Health Strategy (FHS) guidelines, promoted by the Ministry of Health as a mean to overcome the traditional care model ${ }^{(5)}$. One of its potentials is based on the possibility to acknowledge life conditions in a population and, therefore, the social determinants of health, since its objective is performing extramural practices ${ }^{(6-7)}$.

However, although the FHS indicated the overcoming of practices focused on dysfunctional aspects of the biopsychic body, as well as on typical phenomena of the cycle of life phases ${ }^{(8)}$, those practices are still based on programming actions focused on risk factors of priority groups $\mathrm{s}^{(9-11)}$. Consequently, nurses practices have fallen on patients' clinical aspects ${ }^{(7,9-12)}$.

Therefore, traditional practices must expand to reach social inequalities that impact health conditions. Nursing practices and those of other health professionals, when focused on social determinants, promote the improvement of health conditions and the reduction of health inequities ${ }^{(2)}$.

However, there are practices established by the FHS that make possible the identification of health needs, in the context of individual, family and social class, enabling the implementation of practices focused on these health needs.

(a) FAPESP Project: Health needs as the objective of public policies: nursing practices in Primary Care (Process 11/23634-0).
This perspective has been guided by the World Health Organization (WHO), through the Commission on Social Determinants of Health (CSDH). It indicates that governments, civil society and academics should develop articulated actions to act upon social determinants of health (SDH) to reduce avoidable social inequities and, consequently, avoidable diseases ${ }^{(13)}$. Lack of income, insecure work and unsuitable housing are social determinants that generate health inequities ${ }^{(14)}$.

The SDH determine the unequal distribution of diseases and are related to the direction taken by social policies proposed by the State for fair and equitable distribution of access to socially produced wealth ${ }^{(15)}$.

Systematic reviews of relevant literature connects improvement of the population's health conditions with actions aimed at social determinants ${ }^{(16-19)}$.

One of these reviews associated employment and income to social well-being and equity, which improved health conditions ${ }^{(16)}$. Another review related flexible working to formal workers' well-being and health conditions ${ }^{(17)}$. Another associated social determinants of health to life conditions ${ }^{(18-19)}$. Another review associated urbanization of slums to improvement in the population's health patterns ${ }^{(18)}$, and another associated better housing conditions facing the dynamics established between poverty and precarious health conditions ${ }^{(19)}$.

Among the health workers practices focused on health inequities, the potential of nursing practices is emphasized $^{(15,20)}$, especially those focused on individual and collective care by means of a critical approach, that enables the understanding of the context of social inequalities and proposes dealing with these inequalities ${ }^{(15)}$.

Nursing practices were defined as a labour. According to Marx ${ }^{(21)}$ labour is a human activity that is intended and predicted from the beginning (labour purpose), in order to transform an object into a product, by means of instruments and human actions. The labour-process disappears in the product, which answers to the human needs that generated it. Therefore, there is a cycle between labourprocesses and the needs that generate them.

Health needs are defined as social reproduction needs ${ }^{(22)}$ of individuals from social classes. In other words, health needs have their roots in the unequal insertion of subjects in ways of working and in the consequent life conditions (social determinants of health-sickness processes); therefore, they are heterogeneous ${ }^{(4)}$. Hence, as a result, sickness or aggravations are unequally manifested in the bodies of individuals ${ }^{(23)}$.

Since health practices are labour, there is a cycle in health labour-processes and health needs, and also consubstantiality between the elements in them. Health labour products are the answers to the needs that, in their turn, are triggers of health labour-processes ${ }^{(22)}$. 
Therefore, it is understood that in primary care, the purpose of labour-processes is the improvement of health needs for individuals and families from different social classes on a certain territory, taking public health policies into the universal rights direction ${ }^{(4)}$. For that reason, health labour must take health needs as object, not only the sickness.

Under this understanding, it was taken for granted that the Family Health Strategy (FHS) would include emancipatory practices performed by nurses, answering to health needs.

Based on these considerations, the objective of the present study was to identify emancipatory practices of primary care nurses with the purpose of contributing to the improvement of health care.

\section{METHOD}

Social case study ${ }^{(24)}$ research of a qualitative nature. The family health unit (FHU) in this study is located in the Health Supervision Unit of Butantã, part of the Health Coordination of the Center-West region in the city of São Paulo. This unit was intentionally chosen because it is the first FHU in this Health Supervision to implement the Family Health Strategy (FHS) by using all teams and because it is well known for working under participative management and for being committed to the discussion and development of therapeutic projects aligned with the purpose of improving the health conditions of the population described here.

Participants were eight nurses interviewed in the second and third quarter of 2012. The interviews consisted of questions about summaries of the practices performed by them in their daily work routine. These interviews were transcribed and the statements were analyzed in the light of analytical categories: health labour and health needs.

This study derives from research about nursing practices, approved by the Research and Ethics Committee of the Nursing School of the University of São Paulo (process No. 1104/2011) and the Municipal Department of Health of the city of São Paulo (statement No. 037/12). The participants were identified by the letter $E$, followed by the number of the interview, to ensure anonymity, according to resolution $466 / 2012$.

\section{RESULTS}

Interviewees were between 30 and 40 years old; they have been working as nurses for eight years, on average; and within this period, they had worked mostly in primary care. Five of the nurses had completed a specialized course in primary health or family health care, one of them had a master's degree, another one had a doctorate and the last one was finishing a doctorate.

In the daily routine of the $\mathrm{FHU}$, nurses reported the overriding development of practices established by the FHS, mainly focused on individual clinical aspects (laboratory exams; nursing consultations; outreach; home visits (HV); health education groups; epidemiologic surveillance; administrative activities; and the supervision of health community agents). However, they verbalized the possibility of enhancing this perspective, as expressed in the following interview remarks.

The Family Health Program can penetrate the lives of people in a different way from (...) just having their consultations and then leaving. Because we get to know the whole family, we know where they live, how they live, where they work. So, it's not only the disease that matters, we have the opportunity to encourage people to search for ways to improve their lives (E7).

An important aspect to be approached regards the fact that in the FHU of the present study, a lot of meeting modalities were observed to compose spaces for discussion, reflection and enabling the systematization of labour-processes, to incorporate social health needs in the hegemonic object - the disease. These meetings were also places for the formation and improvement of workers' practices, with a view to the improvement health conditions of the population care for by these teams, as described below.

\begin{abstract}
We search not only to monitor the territory, know the most prevalent illnesses, incidences, make the notifications, take measures to handle the cases, but also to search for planning preventive actions, discussions, reflections about the illnesses emerging in the collective scope and to organize all this collective scope for dealing with these situations. (...) We look for acting on the determinants that (...) propagate some diseases (E8).
\end{abstract}

This process unfolded in the discussion of purposes and of the elements involved in the team labour-processes, as demonstrated in the following excerpt.

\begin{abstract}
(...) reflecting on the labour-process, taking a breath for stopping and thinking where our work is inserted, where the public policies are inserted, where the social determination reference of the sickness-health process are inserted, the workers' health... (...) We keep on passing on our practices as from what is discussed there (...). Therefore it is for the understanding of the labour-process, we are trying to get away from alienation (...), and this is the main objective (E6).
\end{abstract}

From another perspective, this study demonstrated that home visits (HV) performed by nurses are an instrument for the identification of health needs. In accordance with the enhanced purpose of the FHU care project, this instrument enabled the implementation of practices that go beyond the individual scope, extending to the social determinants of the collective, according to what is expressed in the following statement.

There are the cases (...) where we care individually, but we tend to go over territorial issues, not to think only about the disease (...). The first time we had a flood, we went to the houses of people to see how they were and we were
Emancipatory practices of nurses in primary health care: the home visit as an instrument of health needs assessment Campos CMS, Silva BRB, Forlin DC, Trapé CA, Lopes 10 
concerned about leptospirosis, (...) But it would be a little cynical [if we] arrived in peoples' houses - ei! Clean it with bleach... and go away. So, we thought the PHU [Primary Health Unit] could contribute more. We have always supported this movement, setting up meetings with the population and trying to organize (...) (E4).

Starting with this HV, this FHU started to support meetings with the population to participate, along with them, with the municipal government, in the organization of and collective requests for prevention actions against floods, as expressed in the next statement.

(...) The sanitary surveillance team, along with some users of the health service asked the health unit to organize a process that was later enhanced in the surveillance team, which looked to dealing with the situation through the organization of these people. We called out the public power to take provisions about it. (...) Medium- and long- term action to work with this community in order to reach a change of situation that would affect the whole neighborhood (E8).

The practices developed by the FHU, such as the HV and worker's meetings, resulted in understanding by the living population and working of the unit about their right to health and social policies, by mobilizing them to demand these rights. We can affirm that these are emancipatory practices.

The contribution of FHU to popular mobilization was carried out through making space available for meetings and proposing the methodology in the meetings. The latter had a view to ensuring the possibility of speaking out to everyone, deepening the understanding of causes of the problems and helping in the definition of paths to the next actions. Other social tool was incorporated in the process, as expressed in the following statements.

(...) We established this discussion group [with health services workers and the population] and we called other people, involving the school and young people from the schools (...); so in this group composed of students, workers, coordinators and users of the health service, some letters were written and added to documents and pictures and then forwarded to the sub-mayor's office, about the stream (E6).

(...) [This work] was also able to associate other sectors as the schools and everything that was achieved with this movement. So, we were able to accomplish many things (...). We set the neighborhood on the path to discussion (E8).

Mobilization around issues about the stream favored requests for care services and other health needs, such as lights in public areas and the linear park.

This experience allowed for the population to count on social mobilization as an instrument to improve the territory's conditions. The role of the mediator, initially played by the FHU, was also played by the population, as confirmed by the following excerpt.

One of the things we have in mind is an emancipatory action, we did not want the population to be dependent on others to accomplish the meetings, depending on us to go to the sub- mayor's office. In the beginning it was like this, but now, they have had meetings by themselves, we participate in some of them. They were able to reach the sub-mayor's office by themselves. They only tell us what they did (E8).

Eventually, parting from a care management project that was focused on improving the health conditions of the neighborhood, we were able to observe that a labourprocess aimed at health needs was developed.

\section{DISCUSSION}

The interviewees demonstrated an understanding of the life and work conditions as strong determinants of health conditions. Moreover, they recognize the limits of the health care focused on clinic aspects.

The instrument itself does not expand the labour product; it is coherent with the purpose of the labour-process, determining the design of the object ${ }^{(22)}$ to be transformed.

Therefore, health practices will be expanded if the purpose of the labour-process is related to the enhancement of health needs in social groups and the object is related to these needs. Consequently, expand the program perspective of FHS means incorporating this purpose in social groups care management, in the coverage area of the FHS.

From this perspective, in order to achieve the expansion of these practices, a constant discussion process about the labour-process purpose is necessary, since the workers will be able to base their actions on their the understanding of the purpose of the work. Through the interviews, it was verified that the meeting spaces of the service are very powerful regarding the discussion about the labour-processes.

Parting from the cycle feature of needs and health labour-processes, expanding these practices is possible by identifying the heterogeneity of health needs.

Actions addressed to social determinants promote health equity. Therefore, it is crucial to acknowledge the social inequalities groups, who compose the territory ${ }^{(15)}$.

The HV is an instrument that allows for this acknowledgement. In the FHU, this practice is protocol. It is hegemonically performed under the modes of hygienist education, pointed out in the literature as a coercive and controlled practice ${ }^{(24)}$. Authors have associated the HV with the Prussian German control model, where power from the central spheres, the State, goes beyond the privacy of these families ${ }^{(25)}$.

On the other hand, interviewees reported that from the HV many territorial issues were identified through meetings with the population, and participation of FHU workers in the organization and collective requests for flood prevention actions to the municipal government scopes. 
Therefore, the HV is a labour-process instrument that holds a double dimension. It is an instrument for the acknowledgement of health needs in the collective scope and for health care in the individual and family dimensions.

For the acknowledgement of the object in this process, the health needs, the HV was a primordial instrument. As from this understanding, the instruments that could express the complexity of care were used, for instance the inter-sectorial actions and the emancipatory practices that originated this mobilization and the neighborhood's social participation.

In care for individuals and families, the HV was used by nurses to perform guidelines for procedures related to the care needed for the prevention of leptospirosis, determined by the specific features of social reproduction in which these social group subjects were inserted.

The result was an improvement in the aspects related to the neighborhood (cleaning of the stream, construction of a linear park, street paving and lights), mobilization and empowering social participation, demonstrating the development of emancipatory practices developed by nurses in this FHU.

From this case study, we can learn that emancipatory practices enable

reflection about the origin of health problems, overthrowing the already-existing problems to reach the determinants of the sickness-health process (...). They empower the social groups' subjects to access their rights and fight for them, (...) they motivate solidarity values, (...) rescue the human social condition as opposed to the subject as a biological being ${ }^{(1)}$.

The nurses' work, since it is care-centered, has better possibilities of coordinating practices to reduce social inequities $^{(20)}$

For this purpose, it is crucial that health labour-process be able to mobilize subjects - workers and population in the territory - for reflecting on and questioning social inequities, in the light of the socioeconomic structure that benefits keeping the status quo. This enables incorporation of social determinants into the subject of labour ${ }^{(26)}$. It is also essential that new emancipatory instruments improve the social reproduction conditions ${ }^{(27)}$ that are at the root of health needs ${ }^{(4)}$.

\section{REFERENCES}

1. Campos CMS. Necessidades de saúde como objeto das políticas públicas: as práticas do enfermeiro na Atenção Básica [tese livre-docência]. São Paulo: Escola de Enfermagem, Universidade de São Paulo; 2013.

2. Bekemeier B. "Upstream" nursing practice and research. Appl Nurs Res. 2008;21(1):50-2.
Nurses have the potential to start the mobilization processes, since they are present in the routine of health services, forming an intersection between the individual and the collective dimensions with a view to decreasing health inequalities ${ }^{(15)}$.

From this perspective, clinical practice becomes a platform for social practice to promote the protection of health and curing disease, since individual interventions do not reach the roots of inequalities. Expanding the practice scope of nurses, including individuals and families, enables social groups to make decisions and to make choices in the collective scope ${ }^{(20)}$.

In Brazilian Primary Care, institutionalized participation practice by social policy guidelines in health have favored the association with a supervisory practice that enhances individual interests, not necessarily representing the collective scope ${ }^{(8)}$.

This erroneous perspective reduces health needs to the needs of health services under a logic where the clients are identified as consumers and not as subjects with rights, who can fight for something, be mobilized and organize actions to define what they want and how they want social policies ${ }^{(28)}$. Participation in health is only effective when the population is mobilized, organized and fights for accessing their rights, with a view to social equality ${ }^{(8)}$. In order to execute interventions, nurses need to develop a critical care approach that enables understanding the inequality context and dealing with it through analyzing public policies ${ }^{(15)}$.

\section{CONCLUSION}

The health labour-processes that allow for the ideas that health conditions can be understood as arising from social relations, and the concept of health as a right, favor the development of emancipatory practices. Regarding health workers, they guide their labour purpose and regarding population, this process allows for an appropriation of the working and living conditions to which they are submitted to.

This present study intends to contribute for the improvement of nursing practices in Primary Care.

3. Mckenzie R. The personal must be the political: how and why. J Psychiatr Ment Health Nurs. 2007;14(3):223-5.

4. Campos CMS, Soares CB. Necessidades de saúde e o cuidado de enfermagem em saúde coletiva. In: Soares CB, Campos $\mathrm{CMS}$, organizadores. Fundamentos de saúde coletiva e o cuidado de enfermagem. São Paulo: Manole; 2013. p. 265-92. 
5. Brasil. Ministério da Saúde; Secretaria de Atenção à Saúde, Departamento de Atenção Básica. Política Nacional de Atenção Básica. Brasília; 2007.

6. Martins AR, Silveira DS, Siqueira FV, Facchini LA, Piccini RX, Tomasi $E$, et al. Práticas dos trabalhadores de saúde na comunidade nos modelos de atenção básica do Sul e Nordeste do Brasil. Cad Saúde Pública. 2010;26(12):2279-95.

7. Shimizu HE, Rosales C. As práticas desenvolvidas no Programa Saúde da Família contribuem para transformar o modelo de atenção à saúde? Rev Bras Enferm. 2009;62(3):424-9.

8. Soratto J, Witt RR, Faria EM. Participação popular e controle social em Saúde: desafios da Estratégia Saúde da Família. Physis Rev Saúde Coletiva. 2010;20(4):1227-43.

9. Ermel RC, Fracolli LA. O trabalho das enfermeiras no Programa de Saúde da Família em Marília/SP. Rev Esc Enferm USP. 2006;40(4):533-9.

10. Facchini LA, Piccini RX, Tomasi E, Thumé E, Silveira DS, Siqueira FV, et al. Desempenho do PSF no Sul e no Nordeste do Brasil: avaliação institucional e epidemiológica da Atenção Básica à Saúde. Ciên Saúde Coletiva. 2006;11(3):669-81.

11. Giovanella L, Escorel S, Mendonça MHM, coordenadoras. Estudos de caso sobre implementação da Estratégia Saúde da Família em quatro grandes centros urbanos: relatório final Aracajú [Internet]. Rio de Janeiro: FIOCRUZ/ENSP; 2009 [citado 2014 Mar 19]. Disponível em: http://www6.ensp.fiocruz.br/repositorio/sites/default/files/arquivos/aracaju.pdf

12. Arantes CIS, Mesquita CC, Machado MLT, Ogata MN. O controle social no Sistema Único de Saúde: concepções e ações de enfermeiras na Atenção Básica. Texto Contexto Enferm. 2007;16(3):470-8.

13. World Health Organization. Closing the gap: policy into practice on social determinants of health: discussion paper. In: World Conference on Social Determinants of Health; 2011 Oct 1921; Rio de Janeiro, Brazil [Internet]. Geneva: WHO; 2011 [cited 2014 Mar 19]. Available from: http://www.who.int/sdhconference/Discussion-paper-EN.pdf

14. World Health Organization. Social determinants of health [Internet]. Geneva; 2007 [cited 2014 Mar 19]. Available from: http://www.who.int/social_determinants/en/

15. Reutter L, Kushner KE. Health equity through action on the social determinants of health: taking up the challenge in nursing. Nurs Inq. 2010;17(3):269-80.

16. Pega F, Carter K, Blakely T, Lucas PJ. In-work tax credits for families and their impact on health status in adults. Cochrane Database Syst Rev. 2013;(8):CD009963.
17. Joyce K, Pabayo R, Critchley JA, Critchley JA, Bambra C. Flexible working conditions and their effects on employee health and well-being. Cochrane Database Syst Rev. 2010;(2):CD008009.

18. Turley R, Saith R, Bhan N, Rehfuess E, Carter B. Slum upgrading strategies involving physical environment and infrastructure interventions and their effects on health and socio-economic outcomes. Cochrane Database Syst Rev. 2013;(1):CD010067.

19. Thomson H, Thomas S, Sellstrom E, Petticrew M. Housing improvements for health and associated socio-economic outcomes. Cochrane Database Syst Rev. 2013;(2): CD008657.

20. Smith GR. Health disparities: what can nursing do? Policy Polit Nurs Pract. 2007; 8(4):285-91.

21. Marx K. O capital: crítica da economia política. São Paulo: Nova Cultural; 1988.

22. Soares CB, Campos CMS, Yonekura T. Marxism as a theoretical and methodological framework in collective health: implications for systematic review and synthesis of evidence. Rev Esc Enferm USP [Internet]. 2013 [cited 2014 Mar 19];47(6):14039. Available from: http://www.scielo.br/pdf/reeusp/v47n6/ en_0080-6234-reeusp-47-6-01403.pdf

23. Gil AC. Métodos e técnicas de pesquisa social. São Paulo: Atlas; 1991.

24. Ribeiro CJ. Problematizando o instrumento visita domiciliar. Soc Debate. 2010; 16(1):209-21.

25. Nascimento MS, Nascimento MAA. Prática da enfermeira no Programa de Saúde da Família: a interface da vigilância da saúde versus as ações programáticas em saúde. Ciên Saúde Coletiva. 2005;10(2):333-45.

26. Blakeman P, Ford L. Working in the real world: a review of sociological concepts of health and well-being and their relation to modern mental health nursing. J Psychiatr Ment Health Nurs. 2012;19(6):482-91.

27. Souza DO, Silva SEV, Silva NO. Determinantes sociais da saúde: reflexões a partir das raízes da "questão social". Saúde Soc. 2013;22(1):44-56.

28. Silva GGA, Egydio MVRM, Souza MC. Algumas considerações sobre o controle social no SUS: usuários ou consumidores? Saúde Debate. 1999;23(53):37-42.

\section{Acknowledgements}

To the São Paulo Research Foundation for financing this research (process No 2011/23634-0). 